\section{Mauritius culls threatened fruit bats}

Mauritius has culled at least 20,000 flying foxes (Pteropus niger), the island's last surviving native species of fruit bat, in an attempt to reduce damage to lychee and mango crops. Ironically, this cull was justified on the basis of a law enacted in late 2015 to improve protection of the country's rich biodiversity.

Pteropus niger is classified by the International Union for Conservation of Nature as threatened with extinction at the 'Vulnerable' level, and was protected under the previous law (F. B. V. Florens Science 336, 1102; 2012).

The 2015 law makes provision for a special technical committee that is tasked with advising the government on the necessity of culling a species in the "national interest". But the decision to cull was announced in parliament before the new bill was enacted, and before the committee could be convened. The cull began within days of the law taking effect.

The biodiversity of Mauritius is among the most threatened worldwide. Consumers need to make an informed choice about supporting its fruit industry, which, in my view, shows disregard for the environment and international conventions. F. B. Vincent Florens University of Mauritius, Réduit, Mauritius. vin.florens@uom.ac.mu

\section{Edited plants should not be patented}

The development of genetically edited crops and plants raises another conundrum - that of intellectual-property protection (see Nature 528, 319-320 (2015) and Nature 529, 265 (2016)). We suggest that, in the interests of all parties, knowledge of these technologies should be made public without prior patenting.

Proponents of gene-editing technologies cannot have it both ways. They hope that edited plants will not be classified as genetically modified organisms, to help to allay public fears. But then the plants would fall under the protection of the International Union for the Protection of New Varieties of Plants (UPOV), which excludes patenting.

A report from the scientific council of the French National Institute for Agricultural Research (INRA) argues that plants bred by any method should not be patented (see go.nature.com/sp15nf; in French). This recommendation is endorsed by the French Senate. Patents are granted for invention, not for having invested in the discovery or manipulation of native genes and sequences. John R. Porter University of Copenhagen, Denmark. Jean-Louis Durand INRA URP3F, Lusignan, France. Taline Elmayan INRA Centre Versailles-Grignon, France. jrp@plen.ku.dk

\section{Tibetan wildlife hemmed in}

The Tibetan Plateau is a hotspot for biodiversity, roughly onethird of which is protected. Yet wildlife conservation efforts there are being disrupted by fences used to manage animal ranges, and by the expansion of roads and railways.

These projects threaten nature conservation and ecosystem health in the region. Affected animals include wild migratory herbivores such as the Tibetan antelope (Pantholops hodgsonii) and Przewalski's gazelle (Procapra przewalskii), both of which are endangered and need large areas of land for grazing and to promote gene flow between populations.

The plateau already has 51,300 kilometres of roads. More are planned, along with extensive railways to connect international borders (see go.nature.com/ whuz3z).
The fences are used to define farm boundaries and to aid rotational farming to reduce grassland degradation (see, for example, Z. Q. You et al. Chinese Sci. Bull. 58, 2262-2268; 2013). Conservation authorities lack the power to override this government policy, which is backed by subsidies that reimburse local households for fence construction.

Policymakers must collaborate to avert the mounting threat to species and their trophic networks in these unique and important alpine ecosystems. Weihong Ji, Achyut Aryal Massey University, Auckland, New Zealand; and Gansu Agricultural University, China. Junhu Su Gansu Agricultural University, China.

j.j.weihong@massey.ac.nz

\section{Balance research funds across Europe}

We call for the European Union to push governments into keeping their research funding above subsistence level. This will ensure that scientists from across Europe can compete for Horizon 2020 research funding, not just those from the United Kingdom, Germany and Scandinavia.

Europe's research money is divided between the European Commission and national governments. The commission funds large, transnational collaborative networks in mostly applied areas of research, and the governments support small-scale, bottom-up science and their own strategic research programmes.

Some member states are not keeping their part of the bargain. Italy, for example, seriously neglects its research base. The Italian National Research Council has not overseen basic research for decades, being itself starved of resources. University funding has dwindled to a bare minimum. The ministerial initiative known as PRIN (Research Projects of National Interest) has been defunct since 2012, apart from a few limited programmes for young researchers.

This year's PRIN allocation of a €92-million (US\$100-million) funding call to cover all research areas is too little, too late. Compare this with the annual French National Research Agency's allocation of up to $€ 1$ billion, or with Italy's $€ 900$-million annual contribution to the EU Seventh Framework Programme that ran in 2007-13. That resulted in a net annual loss of $€ 300$ million for Italian science.

To prevent distorted development in research among EU countries, national policies must be coherent and guarantee a balanced use of resources.

Giorgio Parisi ${ }^{\star}$ University of Rome, Italy. giorgio.parisi@gmail.com ${ }^{*}$ Supported by 69 signatories (listed at go.nature.com/ye2iic).

\section{A toast to the deep-drilling idea}

In your report on the revived drilling project to Earth's mantle, you mention a prominent group of National Academy of Sciences members at the Scripps Institution of Oceanography in California, who met in 1957 to outline the original Project Mohole (Nature 528, 16-17; 2015). The year before, I had already put the case for deep drilling through the oceanic crust to reach the Mohorovičić discontinuity (see Science 124, 686; 1956).

The members described their independent conception as happening over a "wine breakfast" by the ocean. This somewhat louche setting could not be a classed as a cocktail party, as you would have it. That might have been more accurate in my case, when a proper dry Martini at sunset may well have been involved.

Frank B. Estabrook Jet Propulsion Laboratory, California, USA. festabrook@earthlink.net 